\title{
Close Versus Limited Open Method of Ender's Nail Fixation in Paediatric Femoral Shaft Fractures
}

\author{
Rajeev Dwivedi, ${ }^{1}$ Shambhu Sah, ${ }^{2}$ Mukund Dahal, ${ }^{2}$ Parimal Acharya, ${ }^{3}$ Sandeep Gurung, ${ }^{4}$ \\ 'Department of Orthopaedics, Lumbini Medical College Teaching Hospital ,Tansen Palpa ,Nepal, ${ }^{2}$ Department of Orthopaedics, \\ Koshi Zonal Hospital, Biratnagar, Koshi, Nepal, ${ }^{3}$ Department of Orthopaedics, Civil Service Hospital, Kathmandu, Nepal, \\ ${ }^{4}$ Department of Orthopaedics, Nepalguni Medical College, Kohalpur, Nepal.
}

\section{ABSTRACT}

Introduction: There are various surgical options for treating fracture of femoral shaft in children. Here we compare the results of close with limited open method of Ender's nails fixation of femoral shaft fractures in children.

Methods: We studied 60 children with femoral shaft fractures in age group 5-15 years. Ender's nail fixation was done by close technique in 40 cases and in 20 cases by limited open technique.

Results: The mean operative time was significantly high in limited open group being 64 minutes in comparison to 50 minutes in close group. There was no significant difference between close and limited open groups with respect to time for partial weight bearing and time for full weight bearing. Fracture united sooner in close group as compared to open group. Union was achieved in all patients within a mean of 11 weeks in close group in comparison to 12.4 weeks in open group. According to the Flynn criteria in close group 34 patients had excellent results, 6 had satisfactory and none poor. In limited open group outcome was excellent in 14 patients, satisfactory in 4 patients and 2 had poor result. There was no significant difference in outcome based on Flynn criteria between two groups.

Conclusions: Though operative time is more and healing is delayed in Ender's nail fixation by limited open technique, there is no statistical difference in final outcome as per Flynn criteria between close and limited open technique of Ender's nail fixation of femoral shaft fractures in children.

Keywords: children; close technique; ender's nail; fracture shaft of femur; flynn criteria.

\section{INTRODUCTION}

Femoral shaft fractures are among the most common major pediatric injuries treated by Orthopedic surgeons. ${ }^{1}$ Treatment ranges from strictly nonsurgical methods (eg, closed reduction and spica casting or traction followed by spica casting) to surgical stabilization (using intramedullary devices, external fixation, or internal fixation with plate and screws). ${ }^{1}$ Casting with or without traction is still the preferred treatment for isolated femur fractures in children of preschool age. ${ }^{1}$ For children above five years of age option of surgical treatment is increasing because it has advantage of early mobilization, reduced duration of hospital stay and reduced psychological adverse impact. Flexible intramedullary nails (Ender's and titanium elastic nails), external fixation, compression plating and locked rigid intramedullary rod are the available options for fixing femoral fractures in children.

In the present study, we compared the outcomes of close Ender's nailing with Ender's nailing by limited open technique in pediatric femoral shaft fractures.

Correspondence: Dr. Rajeev Dwivedi, Department of Orthopaedics, Lumbini Medical College and teaching hospital, Palpa, Nepal. Email: rd172002@gmail.com, Phone:+977-9851091933. 


\section{METHODS}

The present prospective study was conducted in the Department of Orthopaedics at Nepalgunj Medical College and Teaching Hospital, Kohalpur from June 2009 to November 2011. We included children between five to 15 years with displaced femoral shaft fractures from a point five centimetre $(\mathrm{cm})$ distal to lesser trochanter to $5 \mathrm{~cm}$ proximal to distal femoral physis. A written informed consent was obtained from the family for inclusion in this study. Children more than 15 years and less than five years of age, children with pathological fracture and with open fracture were excluded from the study.

The reșults were evaluated using Flynn's scoring criteria. Major postoperative complication were defined as nonunion, delayed union, infection, refracture, nail irritation requiring hardware removal and nail breakage. Minor postoperative complications were defined as nail irritation that resolved without intervention, asymptomatic nail migration, and any perioperative problem that resolved without surgical intervention or early hardware removal.

\section{Operative Technique}

Nail diameter was chosen on the basis of $40 \%$ of the narrowest intracortical diameter. Approximate length of the nail was determined by measuring on x-rays and on normal side from tip of greater trochanter to adductor tubercle. Final thickness and length of the nail was determined intraoperatively. Nails were bent in an even curve. Surgery was done on fracture table. In every case close reduction was attempted first under fluoroscopic guidance. In case of failure of close reduction, fracture site was opened by limited incision centered over fracture site. After incising the skin, insertion points were made, one on medial and another on lateral side of distal femur, $2.5 \mathrm{~cm}$ proximal to the distal epiphyseal plate. The nails were introduced right up to fracture site. Then, one of the nail was passed across the already reduced fracture site followed by second nail. The nails were directed in such a way that medial nail was introduced into the neck and lateral just below trochanteric apophysis in a fan shaped manner. Two divergent nails were used.

\section{Statistical Analysis}

Comparison of time for union was made between patients treated with close and limited open technique. Statistical significance of this comparison was determined with an unpaired Student $t$ test $(P<.05)$. Comparison between close and limited open group was made regarding operative time, time to initial and full weight-bearing, time to achieve knee range of motion (ROM), and outcomes as per Flynn criteria $(P<.05)$.

\section{RESULTS}

Sixty children with sixty femoral shaft fractures were treated with Ender's nails in this series. In 40 children, surgery was done by close method and in remaining 20 cases reduction was achieved by limited open technique. There were 36 males and 24 females with a mean age of 9.82 (range 5-15) years. The Right femur was fractured in 36 patients and left femur in 24 patients. No cases with bilateral femur fractures were seen. Mechanisms of injury were fall from height in 30 patients; road traffic accident 20, and 10 had injury while playing. Communited fractures were classified according to Winquist system. ${ }^{3}$ Fracture characteristics are documented in table 2. Mean time from injury to surgery was 2.9 (range 2-6) days in close group and 3 days (range 2-7) days in limited open group. The mean hospital stay in close and limited open group was 6.9 and 7.5 days respectively. In close group, antegrade nailing was done in 2 cases whereas in 38 cases nails were inserted in a retrograde manner. In open group, in all cases retrograde nailing was done. The mean operative time was significantly high in limited open group. Mean operative time was 64 minutes in limited open group in comparison to 50 minutes in close group ( $p$ value $=0.000$ ). In two cases, opposite cortex was perforated but nails were introduced by changing the direction of nail tip. In sixteen cases, initial assessment of thickness and length of nails were not appropriate so there was need of exchanging them with different thickness and length. In two patients in limited open group, blood transfusion was done due to symptomatic tachycardia and drop in hemoglobin.

Postoperatively, no patient was given any protective splint. Knee bending and quadriceps strengthening exercises were begun as soon as patient was comfortable. There was not significant difference between close and limited open groups with respect to time for partial weight bearing and time for full weight bearing. Average time to partial weight bearing was 3.8 (2-6) weeks in close group and 3.9 (2 - 6) weeks in open group $(p=.808)$. The average time to full weight bearing was $8(6-12)$ weeks in close group

and $8.2(6-12)$ weeks in open group $(P=.68)$. Fracture united sooner in close group as compared to open group. Union was achieved in all patients within a mean of $11(8-16)$ weeks operated by close technique in comparison to 12.4 (8 to 18) weeks in open group ( $\mathrm{p}=.033$ ). There wasn't significant difference in duration to regain knee ROM between two groups. Full 
Dwivedi et al. Close versus limited open method of Ender's Nail fixation in paediatric femoral shaft fractures

movement of knee was achieved in 9 weeks in close group and 9.4 weeks in open group $(P=0.59)$.

The mean follow up was eight months (6 to 16 months). Outcomes of close and limited open group are shown in table 3 and 4 . In close group, angular deformity more than 5 degree was observed in four patients. Two patients had varus angulation of $8^{\circ}$ and $6^{\circ}$ respectively whereas one had valgus angulation of $8^{\circ}$ and another had anterior angulation of $10^{\circ}$. On clinical examination, lengthening of more than $1 \mathrm{~cm}(1.2 \mathrm{~cm})$ was observed in one patient. In one case skin irritation due to nail was observed that subsided without intervention. On clinical examination significant malrotation was not seen in any patient.

In open group, angulation more than 5 degree was seen in three patients; 7 degree varus, 9 degree valgus and 15 degree valgus respectively. Shortening of more than $1 \mathrm{~cm}$ was observed in two cases; $1.5 \mathrm{~cm}$ and $2.2 \mathrm{~cm}$ respectively. In one patient skin irritation due to hard ware was seen that subsided ${ }_{2}$ without intervention. According to the Flynn criteria, in closed group 34 patients had excellent result, six had satisfactory and none poor. In limited open group outcome was excellent in 14 patients, satisfactory in four patients and two had poor result (table 5). There was no significant difference in outcome based on Flynn criteria between two groups $(p=0.10)$

\begin{tabular}{|c|c|c|c|}
\hline & EXCELLENT & $\begin{array}{l}\text { SATISF- } \\
\text { ACTORY }\end{array}$ & POOR \\
\hline $\begin{array}{l}\text { Limb length } \\
\text { discrepancy }\end{array}$ & $<1 \mathrm{~cm}$ & $1-2 \mathrm{~cm}$ & $>2 \mathrm{~cm}$ \\
\hline Malalignment & $<5$ degree & $\begin{array}{l}\text { 5-10 } \\
\text { degree }\end{array}$ & $\begin{array}{l}>10 \\
\text { degree }\end{array}$ \\
\hline Pain & none & None & Present \\
\hline Complication & none & Minor & Major \\
\hline
\end{tabular}

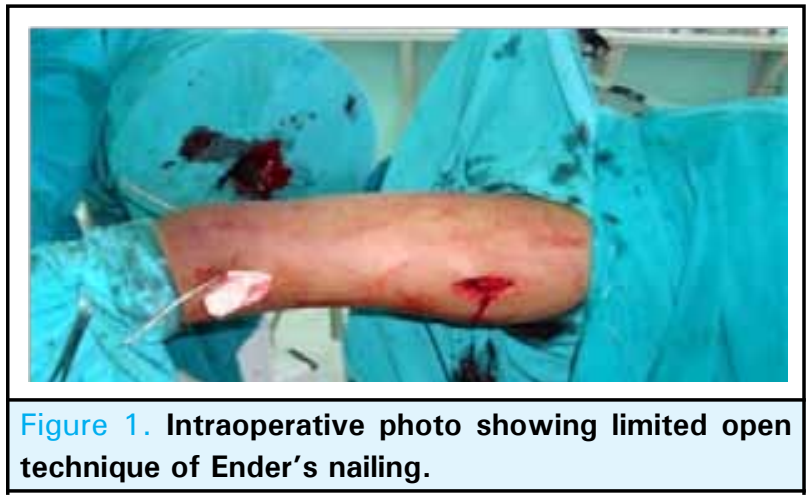

\begin{tabular}{|c|c|c|c|c|}
\hline & & & $\begin{array}{l}\text { Closed } \\
\text { group }\end{array}$ & $\begin{array}{l}\text { Open } \\
\text { group }\end{array}$ \\
\hline \multirow{3}{*}{$\begin{array}{l}\text { Fracture } \\
\text { location }\end{array}$} & \multicolumn{2}{|l|}{ Mid shaft } & 24 & 13 \\
\hline & \multicolumn{2}{|l|}{ Proximal } & 9 & 4 \\
\hline & \multicolumn{2}{|l|}{ Distal } & 7 & 3 \\
\hline \multirow{8}{*}{$\begin{array}{l}\text { Fracture } \\
\text { pattern }\end{array}$} & \multicolumn{2}{|l|}{ Transverse } & 20 & 6 \\
\hline & \multicolumn{2}{|l|}{ Oblique } & 8 & 4 \\
\hline & \multicolumn{2}{|l|}{ Spiral } & 6 & 2 \\
\hline & \multirow{5}{*}{$\begin{array}{l}\text { Communition } \\
\text { on Winquist } \\
\text { grading }\end{array}$} & Total & 6 & 8 \\
\hline & & Grade I & 3 & 3 \\
\hline & & Grade II & 2 & 3 \\
\hline & & $\begin{array}{l}\text { Grade } \\
\text { III }\end{array}$ & 1 & 1 \\
\hline & & $\begin{array}{l}\text { Grade } \\
\text { IV }\end{array}$ & 0 & 1 \\
\hline
\end{tabular}

Table 3. Satisfactory outcomes.

\begin{tabular}{|lll|}
\hline & Closed group & Open group \\
$\begin{array}{l}\text { 5-10 varus /valgus } \\
\text { angulation }\end{array}$ & 3 & 2 \\
$5-10$ anterior/ & 1 & 0 \\
posterior angulation & & \\
$1-2 \mathrm{~cm}$ LLD & 1 (lengthening) & 1 (shortening) \\
$\begin{array}{l}\text { Soft tissue irritation } \\
\text { by }\end{array}$ & 1 & 1 \\
Hardware & & \\
Total & 6 & 4 \\
\hline
\end{tabular}

Table 4. Poor outcomes.

\begin{tabular}{|lll|}
\hline & $\begin{array}{l}\text { Closed } \\
\text { group }\end{array}$ & Open group \\
10-20 varus /valgus & - & 1 \\
Angulation & & \\
$10-20$ & - & - \\
anterior/posterior & & \\
angulation & & 1 \\
$>2$ cm LLD & & (shortening) \\
Total & 0 & 2 \\
\hline
\end{tabular}




\begin{tabular}{|llll|}
\hline \multicolumn{4}{|l|}{ Table 5. Outcomes according to Flynn Criteria. } \\
\hline & Excellent & Satisfactory & Poor \\
Close group & 34 & 6 & 0 \\
Limited open group & 14 & 4 & 2 \\
\hline
\end{tabular}

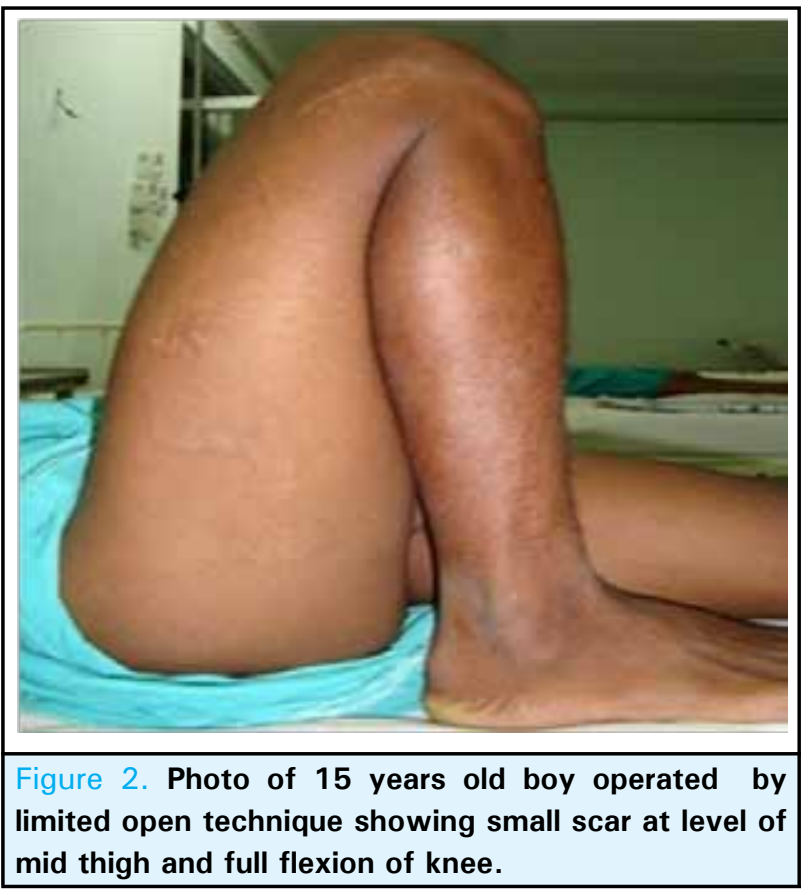

\section{DISCUSSION}

There are a wide range of conservative and surgical options available for the treatment of children with femoral shaft fractures in age group 5-15 years. Conservative (spica) treatment has disadvantages such as prolonged hospital stay, shortening, angular and torsional deformity and the psycho-social implication. These are avoided in surgical treatment with flexible intramedullary nails.4,5 Many orthopedician reserve surgical management only for multiply injured patients. This study aimed to treat isolated femoral shaft fractures surgically by Ender's nails.

External fixation although is associated with minimal soft tissue dissection but it causes patient apprehension on account of external device, high rate of pin track infection and real danger of refracture after removal of fixator. ${ }^{6}$ Compression plating is associated with large soft tissue dissection opening of fracture site and major operation for removal.

Rigid intramedullary nailing may damage the blood supply to the femoral head resulting in avascular necrosis of femoral head or causing growth arrest at the greater trochanter resulting in coxa valga.
Enders nailing is technically simple, time saving and can be done in a closed manner.4 Two divergent ender nails provide adequate fixation and stability. ${ }^{7}$ The major advantages of Ender nail is in healing with abundant callus, attributed to non rigid fixation. ${ }^{8}$ It spares the vascularity and growth plate. It allows early mobilization, rapid external callus formation and rapid restoration of continuity of bones. This results in rapid fracture union and early return to full weight bearing while reducing hospital stay and treatment cost. As per Flynn criteria ${ }^{2}$ results in close group were excellent and satisfactory, there were no poor outcomes. In limited open group, apart from excellent and satisfactory outcomes, there were two poor results but the difference in outcomes between these two groups were not statistically significant. Outcomes of our study matched with several other studies.

Our study matched with Mann et al,(1986).9 They demonstrated excellent results with $100 \%$ union rate without any angular malunions or leg length discrepancies but this study was conducted in older children 9-15 years of age. Karaoglu $S$ and collegues ${ }^{10}$ (1994) reported excellent results in their study but this study was also conducted in children between the ages of 10 and 16 years.

Ozturkmen $Y$ et al, ${ }^{11}$ (2002) reported on twenty six children (mean age 8.9 years, range 5.9 to 12.3 years) they also demonstrated excellent results with Ender's nail in approximately $85 \%$ of patients. Union was achieved in all patients within a mean of 6.6 weeks (range 5 to 12 weeks) and no observation regarding delayed union, infection, nonunion, growth arrest and refracture after nail removal was seen. Laghvendu Shekhar et al,12 (2006) reported in 34 femoral fractures treated by Ender's nail, 20 patients (83.3\%) had excellent result, four $(16.3 \%)$ had satisfactory and none had poor result. Kumar S et al,13 (2011) reported on 62 femoral shaft fractures treated by elastic intramedullary nailing (titanium elastic and Ender's nails) with mean age of the patients being 9.2 years. The result demonstrates $100 \%$ union rate irrespective of the age, weight and height of the patient. They did not find any mismatch in the results of fractures stabilized with titanium elastic nails with that of Ender's nails. Lohiya et al,14 (2011) reported outcomes of flexible intramedullary nailing in 73 femoral shaft fractures. Titanium and Ender's nails were used in 43 and 30 cases respectively. There were overall 59 excellent, 10 satisfactory and four poor results but among Ender's group only one poor result was observed.

\section{CONCLUSION}

Though operative time is more and healing is delayed in Ender's nail fixation by limited open technique, there 
is no statistical difference in final outcome as per Flynn criteria between close and limited open technique of Ender's nail fixation in femoral shaft fractures of children. So Ender's nails fixation either by close or limited open method can be preferred surgical option for the treatment of children with femoral shaft fractures in age group 5-15 years.

\section{REFERENCES}

1. Flynn JM, Schwend RM. Management of pediatric femoral shaft fractures. J Am Acad Orthop Surg. 2004;12(5):347-9.

2. Flynn JM, Hresko T, Reynolds RA, Blasier RD, Davidson R, Kasser J. Titanium elastic nails for pediatric femur fractures:a multicenter study of early results with analysis of complications. J Pediatr Orthop. 2001; 21(1):4-8.

3. Winquist RA, Hansen ST Jr. Comminuted fractures of the femoral shaft treated by intramedullary nailing. Orthop Clin Nort Am. 1980;11:633-48.

4. Mazda K, Khairouni A, Pennecot GF et al. Closed flexible intramedullary nailing of the femoral shaft fractures in children. J Pediatr Orthop. 1997;6:198-202.

5. Gregory P, Sullivan JA, Hernodon WA. Adolescent femoral shaft fractures: rigid versus flexible nails. Orthopedics. 1995;18:645-9.

6. Gregory P, Pevny T, Teaque D. Early complications with external fixation of paediatric femoral shaft fractures. J Orthop Trauma. 1996;10:191-8.

7. Lee S, Mahar AT, Newton PO. Ender nail fixation of pediatric femur fractures a biomechanical analysis. J Pediatr Orthop. 2001:Jul-Aug;21(4):42-5.
8. Yamaji T, Anodo K, Nakamura T, Washimi O, Terada N, Yamada $\mathrm{H}$. Femoral shaft fracture callus formation after intramedullary nailing a comparison of interlocking and Ender nailing. J Orthop Sci . 2002;7(4):472-6.

9. Mann DC, Weddington J, Davenport K. Closed Ender nailing of femoral shaft fractures in adolescents. J Pediatr Orthop. 1986:Nov-Dec;6(6):651-5.

10. Karaoğlu S, Baktir A, Tuncel M, Karakaş ES, Sakir TM. Closed Ender nailing of adolescent femoral shaft fractures. Injury. 1994:Oct;25(8):501-6.

11. Ozturkmen $Y$, Dogrul $C$, Karli M. intramedullary fixation of femoral shaft fractures in children with elastic Enders nail. Acta Orthop traumatol turc. 2002;36(3):220-7.

12. Shekhar L, Mayanger J C. A clinical study of Ender nails fixation in femoral shaft fractures in children. Indian J Orthop. 2006;40:35-7.

13. Kumar S, Roy SK, Jha AK, Chatterjee D, Banerjee D, Garg AK. An evaluation of flexible intramedullary nail fixation in femoral shaft fractures in paediatric age group. J Indian Med Assoc. 2011 Jun;109(6):416-7

14. Lohiya R, Bachhal V , Khan U , Kumar D , Vijayvargiya V , Sankhala S, Bhargava R and Jindal N. Flexible intramedullary nailing in paediatric femoral fractures. A report of 73 cases. Journal of Orthopaedic Surgery and Research. 2011:6:6 